OPEN ACCESS

Edited by:

Shao Hui Huang,

University Health Network, Canada

Reviewed by: loannis Chatzistefanou, Athens Medical Group, Greece

Ricardo D. Coletta, Campinas State University, Brazil

*Correspondence: Lin Que quelin1234567@hotmail.com

Specialty section: This article was submitted to Head and Neck Cancer, a section of the journal

Frontiers in Oncology

Received: 23 March 2021 Accepted: 24 June 2021

Published: 12 July 2021

Citation:

Li J, LiU S, Li Z, Han X and Que L (2021) Prognostic Value of Perineural Invasion in Oral Tongue

Squamous Cell Carcinoma: A Systematic Review and Meta-Analysis.

Front. Oncol. 11:683825.

doi: 10.3389/fonc.2021.683825

\section{Prognostic Value of Perineural Invasion in Oral Tongue Squamous Cell Carcinoma: A Systematic Review and Meta-Analysis}

\author{
Jiajia $L i^{1}$, Shan Liu ${ }^{1}$, Zhangao $L i^{1}$, Xinxin $\mathrm{Han}^{2}$ and Lin Que ${ }^{1 *}$ \\ ${ }^{1}$ State Key Laboratory of Oral Diseases and National Clinical Research Center for Oral Diseases, West China Hospital of \\ Stomatology, Sichuan University, Chengdu, China, ${ }^{2}$ Department of Pediatric Dentistry, School of Stomatology, The Fourth \\ Military Medical University, Xi'an, China
}

Objectives: A significant number of recently published research has outlined the contribution of perineural invasion (PNI) to clinical outcomes in oral tongue squamous cell carcinoma (OTSCC), but some results remain conflicting. This study aimed to determine whether patients with OTSCC with PNI have a worse prognosis than those without PNI.

Materials and Methods: PubMed, Embase, and the Cochrane Library were queried for potentially eligible articles published up to December 2020. The primary outcomes were the hazard ratio (HR) for locoregional recurrence, overall survival $(\mathrm{OS})$, disease-free survival (DFS), and cancer-specific survival (CSS). The random-effect model was used in all analyses.

Results: Seventeen studies (4445 patients) were included. Using adjusted HRs, the presence of PNI was associated with a higher risk of locoregional recurrence $(H R=1.73$, 95\%Cl: 1.07-2.79, $\left.\mathrm{P}=0.025, \mathrm{I}^{2}=33.1 \%, \mathrm{P}_{\text {heterogeneity }}=0.224\right)$, worse OS $(\mathrm{HR}=1.94$, 95\%Cl: 1.39-2.72, $\left.\mathrm{P}<0.001, \mathrm{I}^{2}=0.0 \%, \mathrm{P}_{\text {heterogeneity }}=0.838\right)$, worse DFS (HR=2.13, 95\% Cl: 1.53-2.96, $\left.\mathrm{P}<0.001, \mathrm{I}^{2}=48.4 \%, \mathrm{P}_{\text {heterogeneity }}=0.071\right)$, and worse CSS $(\mathrm{HR}=1.93,95 \% \mathrm{Cl}$ : 1.40-2.65, $\left.\mathrm{P}<0.001, \mathrm{I}^{2}=25.5 \%, \mathrm{P}_{\text {heterogeneity }}=0.251\right)$. PNI had an impact on locoregional recurrence in early-stage OTSCC but not in all stages, and on OS, DFS, and CSS in all-stage and early-stage OTSCC. The sensitivity analyses showed that the results were robust.

Conclusion: The presence of PNI significantly affects the locoregional recurrence and survival outcomes among patients with OTSCC.

Keywords: head and neck cancer, oral tongue squamous cell carcinoma, perineural invasion, survival, meta-analysis, locoregional recurrence 


\section{INTRODUCTION}

Oral squamous cell carcinoma (OSCC) is the sixth most common type of cancer worldwide $(1,2)$, and, among patients with OSCC, oral tongue squamous cell carcinoma (OTSCC) has been reported as the most common cancer found in the oral cavity $(3,4)$. The prognosis of OSCC is generally poor $(1,2,5)$, and the prognosis of OTSCC is even poorer $(6,7)$.

Perineural invasion (PNI) is the result of a complex interaction between invading tumor cells and the particular perineural niche, which has been noted to affect outcomes in many cancers (8-11). PNI is observed in 70\%-100\% of pancreatic cancers, $7 \%-76 \%$ of gastric cancers, $56 \%-88 \%$ of biliary tract tumors, $12 \%-84 \%$ of prostate cancers, $5 \%-90 \%$ of head and neck cancers, $16 \%-39 \%$ of colorectal cancers, and $9 \%-31 \%$ of cervical cancers (8). In all these cancers, PNI is independently associated with poorer prognosis and shorter survival, except for prostate cancer, in which PNI is associated with clinical locoregional recurrence (8). In head and neck cancer, PNI is typically defined by tumor cells invading perineural tissues, tracking along nerves, and/or surrounding at least one-third of the circumference of nerves, and has been defined by the work of Leibig et al. (12), among others (13). In oral cancer, PNI is a high-risk factor for poor outcomes (14). PNI in oral cancer is an indication for radiotherapy and systemic therapy $(5,15-18)$. PNI is a significant predictor of poor outcomes and a requirement for adjuvant therapy in head and neck squamous cell carcinoma (HNSCC) (19-21). PNI is associated with the depth of invasion of OTSCC (22) and cervical lymph node involvement and might suggest consideration for elective neck dissection (23), even in stage 1 and 2 diseases (24). A significant number of recently published research has outlined the contribution of PNI to clinical outcomes in OTSCC (10, 19-21, 25-34). Some authors advocate incorporating PNI in the staging systems for OTSCC (34). Nevertheless, some results remain conflicting.

PNI is usually described in pathological reports, and it may influence the therapeutic management of the patients $(12,13)$. Therefore, this systematic review and meta-analysis aimed to determine whether patients with OTSCC with PNI have a worse prognosis than those without PNI.

\section{MATERIALS AND METHODS}

\section{Literature Search}

This systematic review and meta-analysis was performed according to the Preferred Reporting Items for Systematic Reviews and Meta-Analyses (PRISMA) guidelines (35).

\footnotetext{
Abbreviations: PNI, perineural invasion; OTSCC, oral tongue squamous cell carcinoma; HR, hazard ratio; OS, overall survival; DFS, disease-free survival; CSS, cancer-specific survival; OSCC, oral squamous cell carcinoma; HNSCC, head and neck squamous cell carcinoma; PRISMA, Preferred Reporting Items for Systematic Reviews and Meta-Analyses; CIs, confidence intervals; RCT, randomized controlled study; NOS, Newcastle-Ottawa Scale; MINORS, Methodological Items for Non-Randomized Studies.
}

PubMed, Embase, and the Cochrane Library were queried for potentially eligible articles published up to December 2020, based on the PICO principle (36) and screening according to the eligibility criteria: 1 ) population: patients with OTSCC; 2) exposure: PNI; 3) outcome: prognostic outcome related to survival with a hazard ratio (HR) reported in a Cox regression model; and 4) language limited to English. Supplementary Table S1 presents the search terms. Multiple studies using the same group of patients were considered duplicated; only the most recent article meeting the eligibility criteria was included.

\section{Data Extraction}

Study characteristics (authors, year of publication, country, study design, sample size, and sex and age of the patients), exposurerelated parameters (OTSCC stage and the TMN staging version), and the primary outcome [HR for locoregional recurrence, overall survival (OS), disease-free survival (DFS), and cancerspecific survival (CSS)] were extracted by two investigators (Jiajia $\mathrm{Li}$ and Shan Liu) according to a pre-specified protocol. Locoregional recurrence included local and regional recurrence and DFS encompasses all aspects of the disease (local, regional, and distant). Discrepancies were solved by the discussion by referring to the original paper.

\section{Data Synthesis}

The HRs and their confidence intervals (CIs) that indicated the prognostic outcome were extracted to summarize the prognostic effects of PNI. Whenever the HRs were reported using univariable and multivariable models, the HRs were extracted from the multivariable model with the most covariables.

\section{Quality of the Evidence}

The search ultimately yielded one randomized controlled study (RCT), three prospective cohort studies, and 13 retrospective studies. The level of evidence of RCT and cohort studies was assessed according to the Cochrane Handbook (37), and the Newcastle-Ottawa Scale (NOS) criteria (38), respectively, and Methodological Items for Non-Randomized Studies (MINORS) (39) were used to assess the other studies. Quality assessments were completed independently by two authors (Zhangao Li and Lin Que). Discrepancies in the assessment were resolved through discussion until a consensus was reached. The GRADE method was used to determine the degree of certainty of the outcomes $(37,40)$.

\section{Statistical Analysis}

All analyses were performed using STATA SE 14.0 (StataCorp, College Station, TX, USA). Effects and corresponding 95\% CIs were used to compare the outcomes. Analyses were done separately for the adjusted and unadjusted HRs. Statistical heterogeneity among studies was calculated using Cochran's Q-test and the $\mathrm{I}^{2}$ index. An $\mathrm{I}^{2}$ $>50 \%$ and Q-test $\mathrm{P}$-value $<0.10$ indicated high heterogeneity. The random-effects model was used in all analyses, irrespective of heterogeneity, to account for differences among study populations, treatment regimens, and local practices $(37,41)$. The publication bias was not assessed because each meta-analysis included $<10$ studies, in which case funnel plots and the Egger 
and Begg tests could yield misleading results $(37,42)$. P-values $<0.05$ were considered statistically significant.

\section{RESULTS}

\section{Selection of the Studies}

Figure 1 presents the study selection process. The initial search yielded 229 records; after removing the duplicates, 199 were screened, and 38 were excluded. Then, 161 full-text articles or abstracts were assessed for eligibility, and 144 were excluded: 13 for study design/aim, 51 for the population, 56 for the outcomes, 23 for the intervention, and one for the language. Finally, 17 studies were included in this meta-analysis. Supplementary Table S2 presents the excluded studies.

Table 1 presents the characteristics of the studies (20, 25-32, 43-50), including one RCT (43), three prospective cohort studies (44-46), and 13 retrospective studies (20, 25-32, 47-50). Eight studies were from Asia $(20,30,32,43,44,46,47,50)$, one was Australia (45), three were from Europe (25, 28, 29), and five were from North America (26, 27, 31, 48, 49). The 17 studies included a total of 4445 patients. Supplementary Table S1 shows that the RCT (43) had a low risk of bias. Among the cohort studies, three
$(26,30,49)$ scored 7 stars, four $(27,29,47,48)$ scored 8 stars, and two $(44,45)$ scored 9 stars (Supplementary Table S1). For the other studies evaluated using MINORS, one (32) scored 5 points, five $(20,25,28,31,50)$ scored 6 points, and one (46) scored 8 points (Supplementary Table S3).

\section{Impact of PNI on Locoregional Recurrence and Survival}

Seven $(25,30-32,44,46,49)$ and three $(26,30,32)$ evaluated the non-adjusted and adjusted impact of PNI on locoregional recurrence. The presence of PNI was associated with a higher risk of locoregional recurrence in the non-adjusted $(\mathrm{HR}=1.85$, 95\%CI: $\left.1.41-2.44, \mathrm{P}<0.001, \mathrm{I}^{2}=6.5 \%, \mathrm{P}_{\text {heterogeneity }}=0.378\right)$ and adjusted $\left(\mathrm{HR}=1.73,95 \% \mathrm{CI}: 1.07-2.79, \mathrm{P}=0.025, \mathrm{I}^{2}=33.1 \%\right.$, $\mathrm{P}_{\text {heterogeneity }}=0.224$ ) analyses (Figure $\mathbf{2 A}$ and Table 2).

Three $(30,44,49)$ and two $(26,30)$ evaluated the nonadjusted and adjusted impact of PNI on local locoregional recurrence. The presence of PNI was associated with a higher risk of local locoregional recurrence in the non-adjusted $\left(\mathrm{HR}=2.46,95 \% \mathrm{CI}: 1.59-3.79, \mathrm{P}<0.001, \mathrm{I}^{2}=0.0 \%\right.$, $\left.\mathrm{P}_{\text {heterogeneity }}=0.661\right)$ but not in the adjusted $(\mathrm{HR}=1.93,95 \% \mathrm{CI}$ : 0.83-4.49, $\left.\mathrm{P}=0.126, \mathrm{I}^{2}=64.0 \%, \mathrm{P}_{\text {heterogeneity }}=0.096\right)$ analyses (Figure 2B).

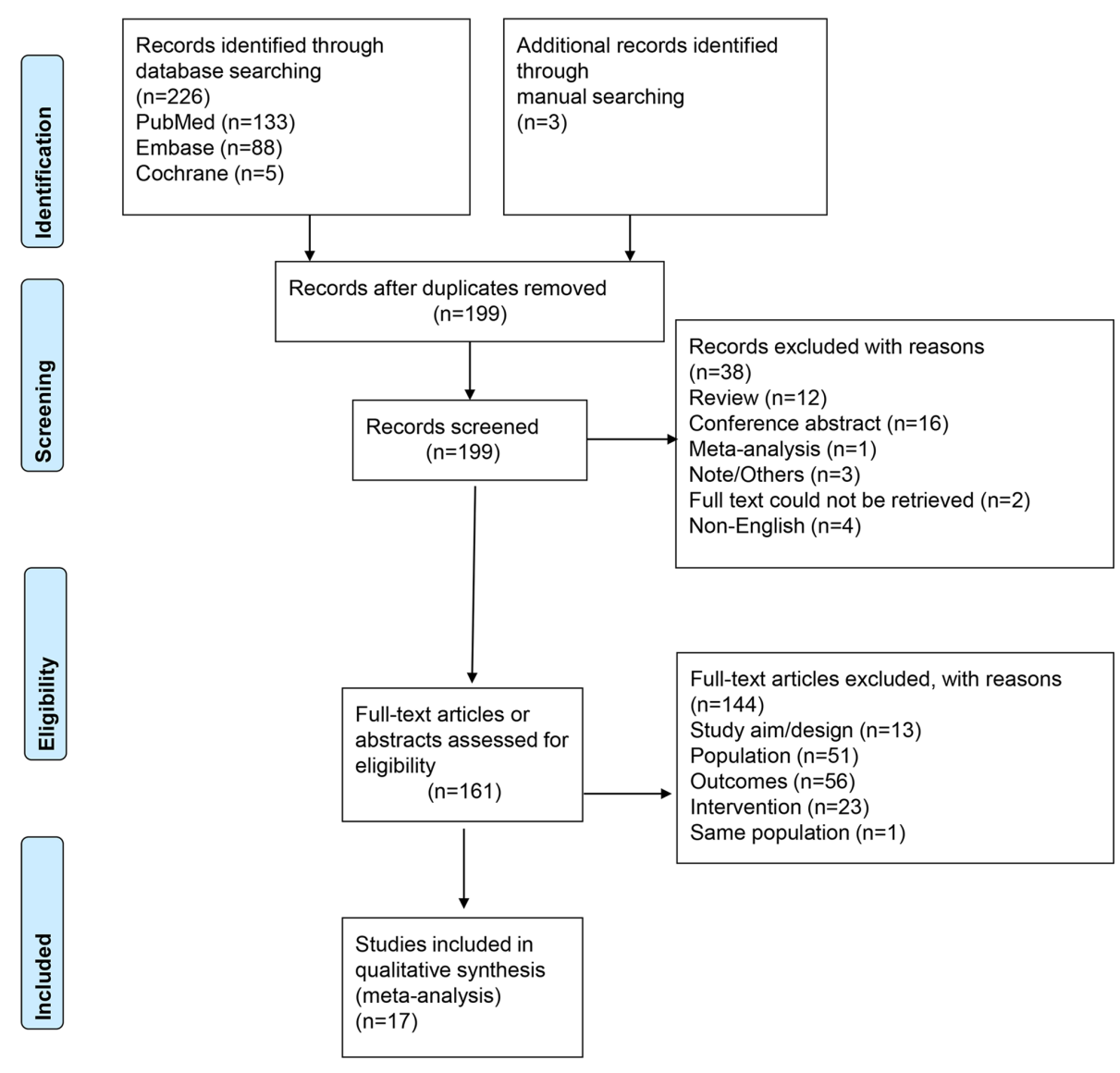

FIGURE 1 | PRISMA 2020 flow diagram. 
TABLE 1 | Literature search and study characteristics.

\begin{tabular}{|c|c|c|c|c|c|c|c|c|c|c|}
\hline Author, year & Country & $\begin{array}{l}\text { Study } \\
\text { design }\end{array}$ & $\begin{array}{l}\text { Sample } \\
\text { size }\end{array}$ & Stage & $\begin{array}{l}\text { TNM } \\
\text { staging } \\
\text { guideline }\end{array}$ & $\begin{array}{c}\text { Male, } \\
\%\end{array}$ & Age & $\begin{array}{l}\text { Uni/ } \\
\text { multivariate } \\
\text { analysis }\end{array}$ & Adjusted factors & $\begin{array}{l}\text { Main } \\
\text { results }\end{array}$ \\
\hline $\begin{array}{l}\text { Yang, } 2018 \\
(43)\end{array}$ & China & $\mathrm{RCT}$ & 221 & $\begin{array}{l}\text { cT1- } \\
\text { T2No }\end{array}$ & AJCC7 & NA & NA & Multivariate & T stage, Pathological grade & $\begin{array}{l}\text { LN, } \\
\text { metastasis, } \\
\text { LR, DFS }\end{array}$ \\
\hline $\begin{array}{l}\text { Choi, } 2017 \\
(44)\end{array}$ & Korea & $\begin{array}{l}\text { Prospective } \\
\text { cohort }\end{array}$ & 75 & $\begin{array}{l}\text { cT1- } \\
\text { T2No }\end{array}$ & NA & 56 & $\begin{array}{c}52.1 \\
(49.0- \\
55.2)\end{array}$ & $\begin{array}{l}\text { Uni/ } \\
\text { multivariate }\end{array}$ & / & LRSF, RRSF \\
\hline $\begin{array}{l}\text { Subramaniam, } \\
2020(45)\end{array}$ & Australia & $\begin{array}{l}\text { Prospective } \\
\text { cohort }\end{array}$ & 425 & All & AJCC7 & 71.8 & $\begin{array}{c}45(18- \\
86)\end{array}$ & Multivariate & / & $\begin{array}{l}\text { OS, DSS, } \\
\text { Recurrent }\end{array}$ \\
\hline Xu, 2020 (46) & China & $\begin{array}{l}\text { Prospective } \\
\text { cohort }\end{array}$ & 120 & $\begin{array}{l}\text { cT1- } \\
\text { T2No }\end{array}$ & AJCC8 & 75.8 & $\begin{array}{c}60(31- \\
75)\end{array}$ & Univariate & / & $\begin{array}{l}\text { Occult neck } \\
\text { lymphnode } \\
\text { metastasis } \\
\text { and LRC }\end{array}$ \\
\hline $\begin{array}{l}\text { Almangush, } \\
2015 \text { (25) }\end{array}$ & Finland & Retrospective & 479 & $\begin{array}{l}\text { cT1- } \\
\text { T2No }\end{array}$ & NA & 54.7 & NA & Univariate & / & $\begin{array}{l}\text { LRR, OS, } \\
\text { CSS }\end{array}$ \\
\hline $\begin{array}{l}\text { Cracchiolo, } \\
2018 \text { (26) }\end{array}$ & USA & Retrospective & 381 & All & NA & 58.3 & $\begin{array}{c}57(18- \\
96)\end{array}$ & $\begin{array}{l}\text { Uni/ } \\
\text { multivariate }\end{array}$ & $\begin{array}{l}\text { Tumor size, adjuvant therapy, and lymph } \\
\text { node status }\end{array}$ & $\begin{array}{l}\text { DSS, LRFS, } \\
\text { RRFS, } \\
\text { DRFS }\end{array}$ \\
\hline $\begin{array}{l}\text { De Paz, } 2019 \\
(47)\end{array}$ & China & Retrospective & 259 & All & AJCC8 & 86.1 & $\begin{array}{c}\leq 51.5 \\
(47.5 \%)\end{array}$ & Multivariate & Age and sex & OS, DFS \\
\hline Durr, 2013 (27) & USA & Retrospective & 120 & All & AJCC7 & 55 & $\begin{array}{c}57.5 \pm \\
15.3\end{array}$ & Multivariate & $\begin{array}{l}\text { Age, sex, race, Smoking status, Charlson } \\
\text { comorbidity score, Overall stage, treatment } \\
\text { characteristics }\end{array}$ & $\begin{array}{l}\text { Recurrence, } \\
\text { OS, RFS }\end{array}$ \\
\hline $\begin{array}{l}\text { Goodman, } \\
2009 \text { (48) }\end{array}$ & USA & Retrospective & 339 & All & NA & 57.5 & NA & Multivariate & Study site & OS \\
\hline Ling, 2013 (20) & China & Retrospective & 210 & All & AJCC6 & 53.8 & $\begin{array}{c}55(22- \\
88)\end{array}$ & $\begin{array}{l}\text { Uni/ } \\
\text { multivariate }\end{array}$ & / & DSS, OS \\
\hline $\begin{array}{l}\text { Marra, } 2019 \\
(28)\end{array}$ & Italy & Retrospective & 106 & All & AJCC7 & 64.1 & $\begin{array}{c}61(51- \\
69)\end{array}$ & Multivariate & / & DFS \\
\hline $\begin{array}{l}\text { Mascitti, } 2020 \\
\text { (29) }\end{array}$ & Italy & Retrospective & 139 & All & AJCC8 & 61.9 & NA & $\begin{array}{l}\text { Uni/ } \\
\text { multivariate }\end{array}$ & TSR, Stage, WHO Grade, Age, and Gender & $\begin{array}{l}\text { DSS, DFS, } \\
\text { OS }\end{array}$ \\
\hline Ong, 2018 (30) & China & Retrospective & 166 & pT2 & NA & 56 & $\begin{array}{c}52.7 \\
(24-70)\end{array}$ & $\begin{array}{l}\text { Uni/ } \\
\text { multivariate }\end{array}$ & / & $\begin{array}{l}\text { LR, DFS, } \\
\text { OS }\end{array}$ \\
\hline $\begin{array}{l}\text { Peng, } 2014 \\
\text { (31) }\end{array}$ & Canada & Retrospective & 123 & cT1NO & AJCC8 & 52 & $\begin{array}{c}56(27- \\
92)\end{array}$ & Univariate & / & $\mathrm{LRC}$ \\
\hline $\begin{array}{l}\text { Sharma, } 2019 \\
\text { (32) }\end{array}$ & India & Retrospective & 202 & All & AJCC8 & 75.7 & $\begin{array}{c}54.2 \pm \\
14.2\end{array}$ & $\begin{array}{l}\text { Uni/ } \\
\text { multivariate }\end{array}$ & $\begin{array}{l}\text { Age, sex, addictions (tobacco smoking, } \\
\text { tobacco chewing and/or alcohol } \\
\text { consumption), tumor grade, pathological T } \\
\text { (pT) stage, pathological } \mathrm{N}(\mathrm{pN}) \text { stage, } \mathrm{PNI} \text {, } \\
\mathrm{LVI} \text {, resection margin status, DOI, and ECE }\end{array}$ & LRR, OS \\
\hline $\begin{array}{l}\text { Sridharan, } \\
2019(49)\end{array}$ & USA & Retrospective & 494 & $\begin{array}{l}\text { cT1- } \\
\text { T3NO }\end{array}$ & AJCC8 & 55 & $\begin{array}{c}59(23- \\
88)\end{array}$ & Univariate & / & LR, LRR \\
\hline $\begin{array}{l}\text { Thiagarajan, } \\
2014(50)\end{array}$ & India & Retrospective & 586 & All & NA & 70.9 & NA & $\begin{array}{l}\text { Uni/ } \\
\text { multivariate }\end{array}$ & / & DFS \\
\hline
\end{tabular}

AJCC, American joint committee on cancer; DFS, Disease-free survival; DSS, disease-specific survival; CSS, Cancer-specific survival; LR, local recurrence; LRC, Locoregional control;

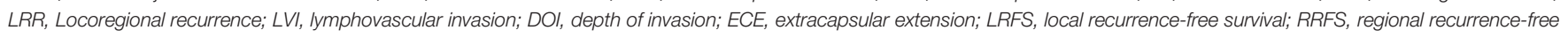
survival; DRFS, distant recurrence-free survival; RFS, recurrence-free survival; /: not available or not applicable.

The presence of PNI was reported with a worse OS (20, 27, 30, $47,48)$ in the adjusted analysis ( $\mathrm{HR}=1.94,95 \% \mathrm{CI}: 1.39-2.72$, $\left.\mathrm{P}<0.001, \mathrm{I}^{2}=0.0 \%, \mathrm{P}_{\text {heterogeneity }}=0.838\right)$ but not in the nonadjusted ones $(25,30,32)(\mathrm{HR}=1.65,95 \% \mathrm{CI}$ : 0.94-2.90, $\mathrm{P}=0.079$, $\left.\mathrm{I}^{2}=65.5 \%, \mathrm{P}_{\text {heterogeneity }}=0.055\right)$ (Figure 3 and Table 2 ).

The presence of PNI was reported with a worse DFS in the adjusted $(27-30,43,47,50)(\mathrm{HR}=2.13,95 \% \mathrm{CI}: 1.53-2.96$, $\left.\mathrm{P}<0.001, \mathrm{I}^{2}=48.4 \%, \mathrm{P}_{\text {heterogeneity }}=0.071\right)$ and unadjusted $(30)$ $(\mathrm{HR}=3.20,95 \% \mathrm{CI}: 1.67-6.14, \mathrm{P}<0.001)$ analyses (Figure 4 and Table 2).

The presence of PNI was reported with a worse CSS in the adjusted analysis $(20,26,29,43,45)(\mathrm{HR}=1.93$, 95\%CI: 1.40-2.65,
$\left.\mathrm{P}<0.001, \mathrm{I}^{2}=25.5 \%, \mathrm{P}_{\text {heterogeneity }}=0.251\right)$ but not in the unadjusted one (25) $(\mathrm{HR}=0.87,95 \% \mathrm{CI}: 0.51-1.48, \mathrm{P}=0.608)$ (Figure 5 and Table 2).

\section{Impact of PNI on Locoregional Recurrence and Survival According to Cancer Stage}

PNI had an impact on the locoregional recurrence of early-stage OTSCC in the adjusted (30) $(\mathrm{HR}=3.08,95 \% \mathrm{CI}: 1.39-6.82$, $\mathrm{P}=0.006)$ and unadjusted analyses $(\mathrm{HR}=1.88,95 \% \mathrm{CI}$ : 1.37-2.59, $\mathrm{P}<0.001, \mathrm{I}^{2}=21.9 \%, \mathrm{P}_{\text {heterogeneity }}=0.269$ ); PNI had no impact on locoregional recurrence in all stages $(26,32)$ (Supplementary Figure S1 and Table 2). PNI had an impact on the locoregional 

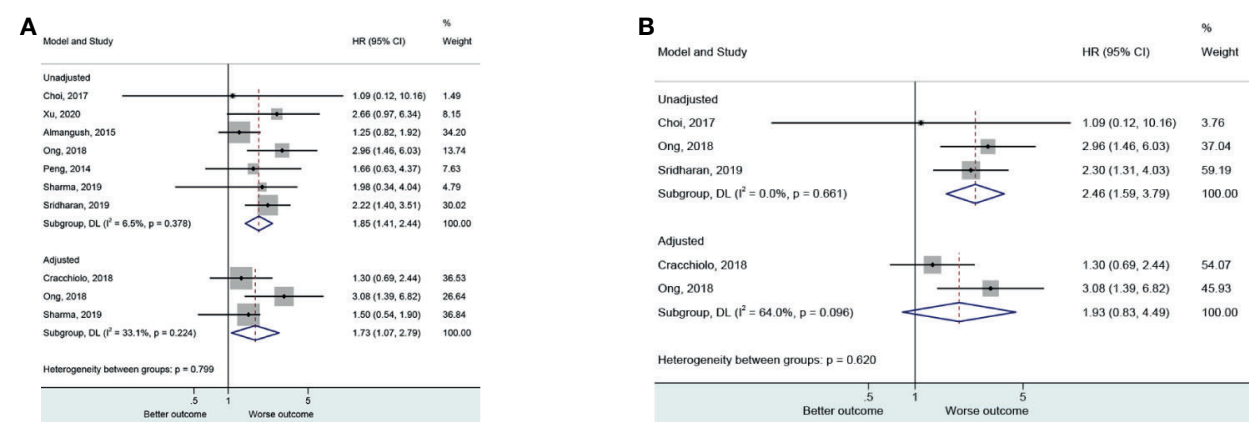

FIGURE 2 | (A) Forest plot for locoregional recurrence (local and regional) according to the applied model (adjusted and unadjusted). (B) Forest plot local recurrence according to the applied model (adjusted and unadjusted).

TABLE 2 | Hazard ratios for the survival outcome.

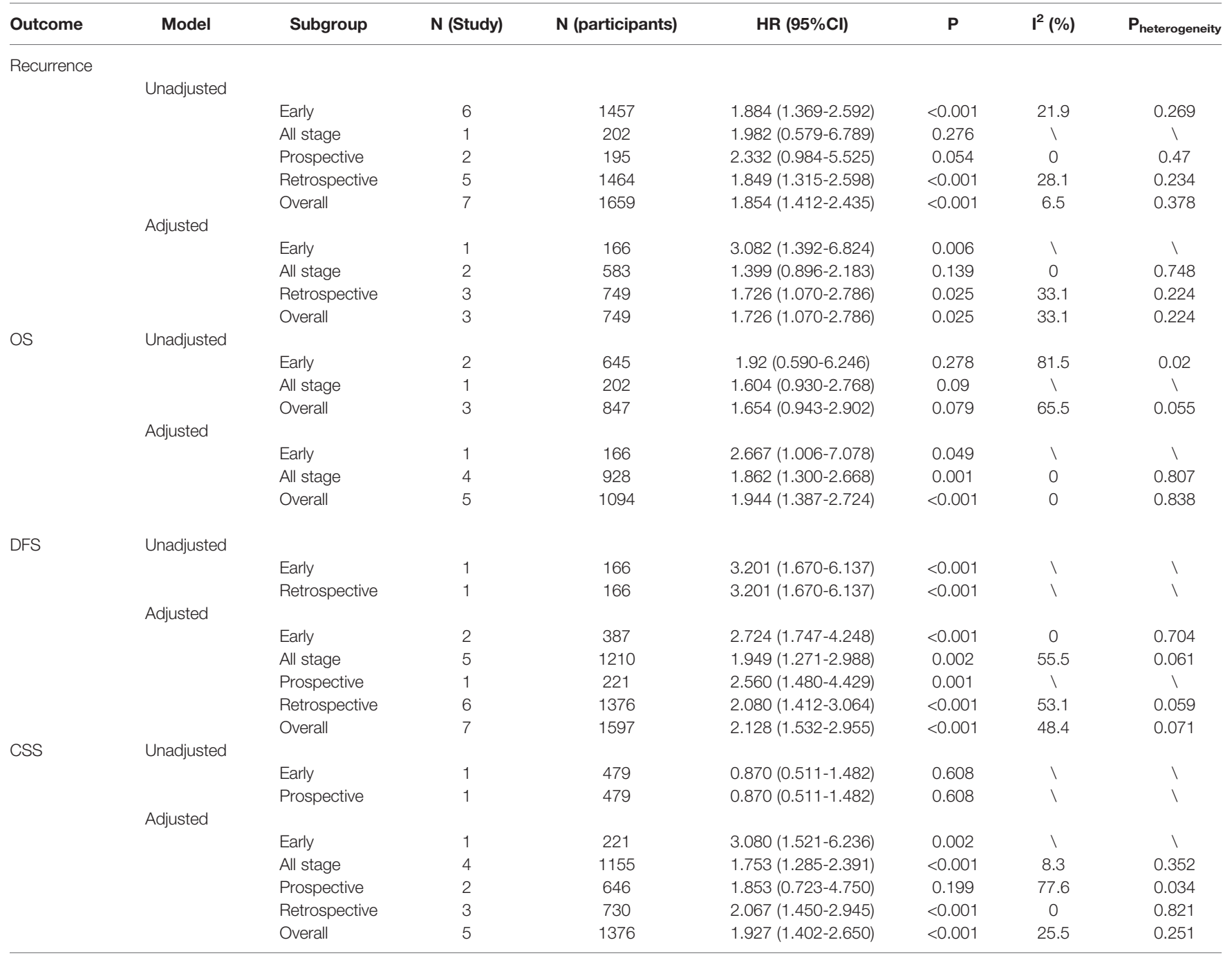

OS, overall survival; DFS, disease-free survival; CSS, cancer-specific survival; /: not available or not applicable. 


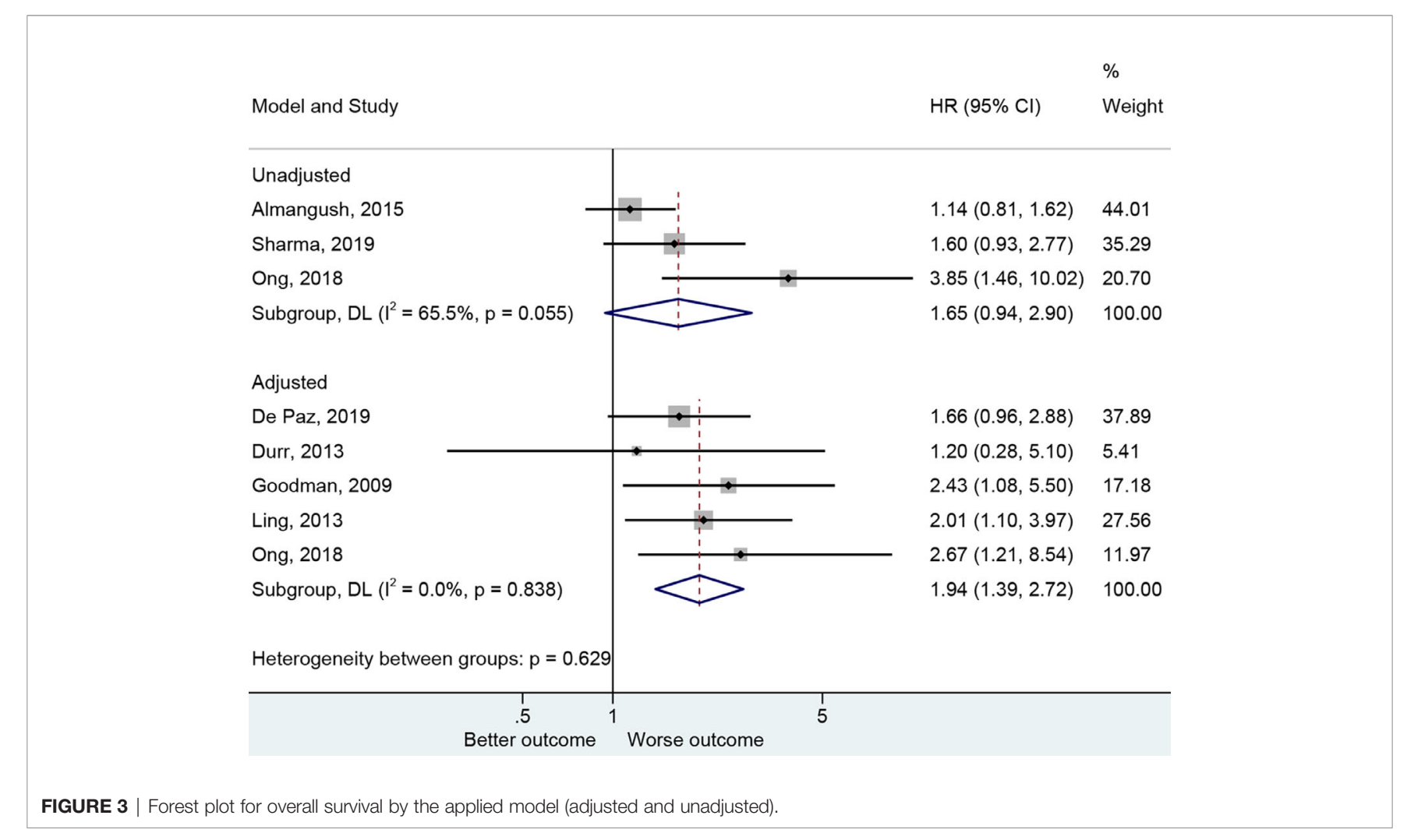

FIGURE 3 | Forest plot for overall survival by the applied model (adjusted and unadjusted).

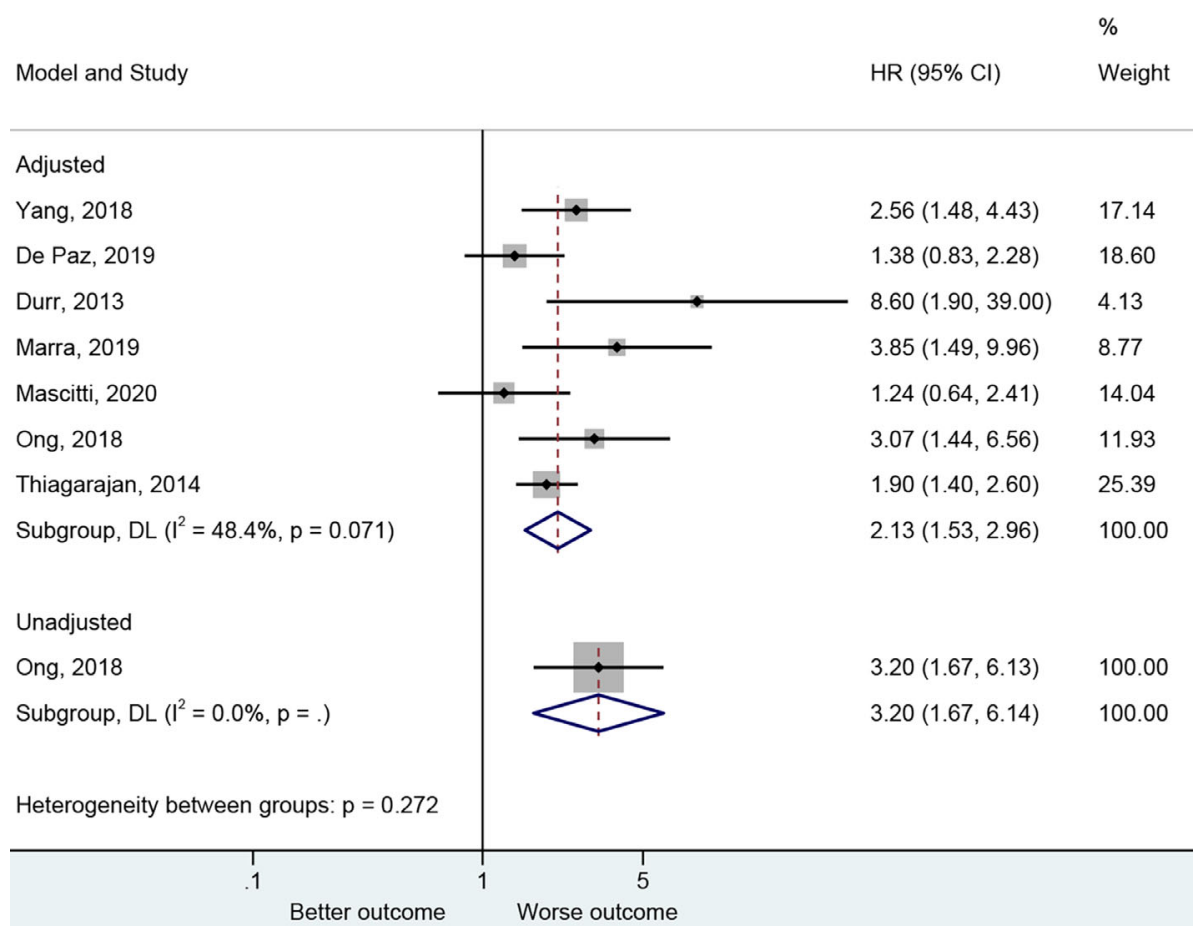

FIGURE 4 | Forest plot for disease-free survival by the applied model (adjusted and unadjusted). 


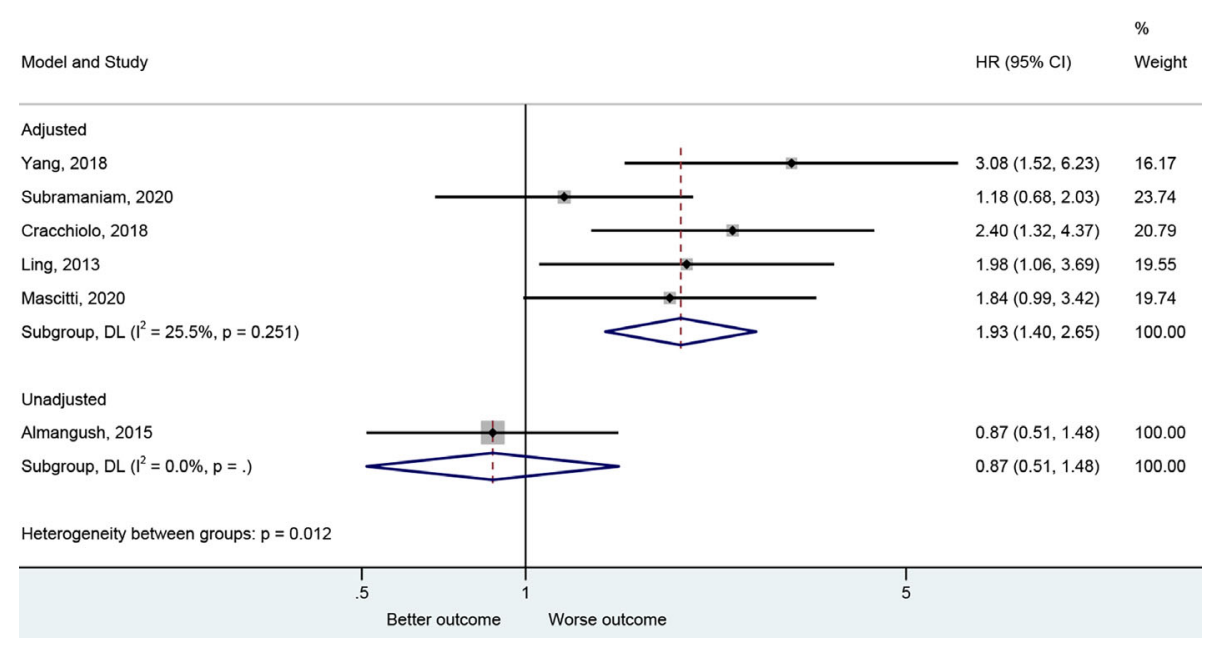

FIGURE 5 | Forest plot for cancer-specific survival by the applied model (adjusted and unadjusted).

recurrence of early-stage OTSCC in retrospective studies (25, $30-32,49)\left(\mathrm{HR}=1.85,95 \% \mathrm{CI}: 1.32-2.60, \mathrm{P}<0.001, \mathrm{I}^{2}=28.1 \%\right.$, $\left.\mathrm{P}_{\text {heterogeneity }}=0.234\right)$ but not in the prospective ones $(44,46)$ (Supplementary Figure S1 and Table 2).

PNI had an impact on the OS of early-stage OTSCC in the adjusted (30) $(\mathrm{HR}=2.67,95 \% \mathrm{CI}: 1.01-7.08, \mathrm{P}=0.049)$ but not in the unadjusted analyses $(25,30)(\mathrm{HR}=1.92,95 \% \mathrm{CI}: 0.59-6.25$, $\left.\mathrm{P}=0.278, \mathrm{I}^{2}=81.5 \%, \mathrm{P}_{\text {heterogeneity }}=0.020\right)$. PNI had an impact on the OS of all-stage OTSCC in the adjusted $(20,27,47,48)$ ( $\mathrm{HR}=1.86,95 \% \mathrm{CI}: 1.30-2.67, \mathrm{P}=0.001)$ but not in the unadjusted analyses (32) $(\mathrm{HR}=1.60,95 \% \mathrm{CI}: 0.93-2.77, \mathrm{P}=0.090)$

(Supplementary Figure S2 and Table 2).

PNI had an impact on the DFS of early-stage OTSCC $(30,43)$ $\left(\mathrm{HR}=2.72\right.$, 95\%CI: $\left.1.75-4.25, \mathrm{P}<0.001, \mathrm{I}^{2}=0.0 \%, \mathrm{P}_{\text {heterogeneity }}=0.704\right)$ and in all-stage OTSCC $(27-29,47,50)(\mathrm{HR}=1.95,95 \% \mathrm{CI}: 1.27-$ 2.99, $\left.\mathrm{P}=0.002, \mathrm{I}^{2}=55.5 \%, \mathrm{P}_{\text {heterogeneity }}=0.061\right)$. Similar results were observed in prospective (43) $(\mathrm{HR}=2.56,95 \% \mathrm{CI}: 1.48-4.43, \mathrm{P}=0.001)$ and retrospective $(27-30,47,50)(\mathrm{HR}=2.08,95 \% \mathrm{CI}: 1.41-3.06$, $\mathrm{P}<0.001, \mathrm{I}^{2}=53.1 \%, \mathrm{P}_{\text {heterogeneity }}=0.059$ ) studies (Supplementary Figure S3 and Table 2).

PNI had an impact on the CSS of early-stage OTSCC (43) $(\mathrm{HR}=3.08,95 \% \mathrm{CI}: 1.52-6.24, \mathrm{P}=0.002)$ and in all-stage OTSCC $(20$, $26,29,45)\left(\mathrm{HR}=1.75,95 \% \mathrm{CI}: 1.29-2.39, \mathrm{P}<0.001, \mathrm{I}^{2}=8.3 \%\right.$, $\left.\mathrm{P}_{\text {heterogeneity }}=0.352\right)$. Similar results were observed in retrospective $(20,26,29) \quad\left(\mathrm{HR}=2.07,95 \% \mathrm{CI}: 1.45-2.985, \mathrm{P}<0.001, \mathrm{I}^{2}=0.0 \%\right.$, $\left.\mathrm{P}_{\text {heterogeneity }}=0.821\right)$ but not in prospective studies $(43,45)$ $\left(\mathrm{HR}=1.85,95 \% \mathrm{CI}: 0.72-4.75, \mathrm{P}=0.199, \mathrm{I}^{2}=77.6 \%\right.$, $\mathrm{P}_{\text {heterogeneity }}=0.034$ ) (Supplementary Figure S4 and Table 2).

\section{Sensitivity Analyses}

The sensitivity analyses showed that the sequential exclusion of each study, in turn, did not affect the results (Supplementary Figure S5). The GRADE analysis suggests that the degree of certainty is high for all four outcomes (Supplementary Table S4).

\section{DISCUSSION}

A significant number of recently published research has outlined the contribution of PNI to clinical outcome in OTSCC $(10,19-$ $21,25-32$ ), but the results remain conflicting. Therefore, this meta-analysis aimed to determine whether patients with OTSCC with PNI have a worse prognosis than those without PNI. The results indicate that the presence of PNI significantly affects the locoregional recurrence and survival outcomes among patients with OTSCC.

PNI results from the complex interaction between invading tumor cells and the particular perineural niche $(8-11)$. PNI is defined by tumor cells invading perineural tissues, tracking along nerves; since nerves travels across a wide number of structures in the head and neck area, the tumor cells can invade a large area $(12,13)$. The currently proposed mechanisms suggest that the perineural microenvironment is favorable to tumor cell growth and mobility. Indeed, the nerve microenvironment includes blood supply and numerous cell types that maintain and support the surrounding neurons, but that can also maintain and support tumor cells $(51,52)$. Several chemokines might also be involved, but their involvement might vary according to cancer type $(53,54)$.

PNI has been reported to be associated with cancer outcomes in various types of cancer (8-11), including HNSCC (19-21) and $\operatorname{OTSCC}(20,27,28,30,43,48,50)$, but the findings in OTSCC are not unanimous $(25,26,31,32,44,46)$. Nevertheless, when synthesized using the meta-analysis methodology, these conflicting studies support that PNI is associated with locoregional recurrence and poor OS, DFS, and CSS. This is supported by a previous meta-analysis of PNI in HNSCC, in which PNI was associated with OS, DFS, and CSS (55). The present study refines the results of the previous meta-analysis by showing that the associations remain true in OTSCC, which is a particularly aggressive subtype of $\operatorname{HNSCC}(5,27)$. In head and 
neck adenoid cystic carcinoma, PNI is independently associated with a poor prognosis, according to a meta-analysis by Ju et al. (56), and the prognosis of PNI was worst in males and young patients, but less definitive results were found by other systematic reviews $(57,58)$. A previous meta-analysis indicated that PNI is a strong factor predicting local recurrence and survival in colorectal cancer and that the prognostic value of PNI was similar to that of the depth of invasion, tumor differentiation, positive lymph nodes, and lymphatic and extramural invasion (9). In invasive cervical carcinoma, PNI is associated with OS but not with DFS (59). Previous meta-analyses also reported similar results for esophageal carcinoma (60), gastric cancer (61, 62), and rectal carcinoma (63). The present study provides further evidence that PNI is also associated with the outcomes of OTSCC. Of course, the magnitude of the association might vary among different types of cancer. Future studies could aim at quantifying these differences. In addition, the characteristics of PNI (i.e., size of the involved nerves, number of foci and involved nerves, and intratumoral or peritumoral localization) influence the prognostic significance of PNI (64-66). In the present metaanalysis, the characteristics of PNI were not consistently reported among the included studies, and the number of studies was too small for stratified analyses. Future studies should examine the characteristics of PNI more closely.

Hence, PNI is a prognostic marker in OTSCC. PNI could be used as a marker for more aggressive management in patients with OTSCC. Indeed, the presence of PNI has been suggested to guide the management of various cancers, like skin squamous and basal cell carcinoma (67), oral cancer (68), and colorectal cancer (69). Of note, Yang et al. (43) showed that elective neck dissection did not improve the prognosis in patients with OTSCC and PNI. This implies that surgery, which aims at macroscopic disease, might not be adequate for this type of OTSCC and that modalities targeting the microscopic disease, like radiotherapy and systemic therapy, might be more appropriate. Still, it will have to be examined in future studies.

This study has limitations. Firstly, even though 4445 patients were included in this study, the number of prospective studies was small, indicating that the results might be influenced by the biases inherited from the retrospective studies. In such instances, the quality of evidence of the analysis would be undermined. Secondly, we were interested in examining the impact of PNI on the survival outcomes among patients with OTSCC of different stages as we assumed that PNI could be incorporated as a reliable predictor into the current staging guidelines. Although a subgroup analysis for the stage was performed, there are a few points that need to be addressed before concluding about the assumption that PNI is associated with survival. First, only a few numbers of studies investigated early-stage OTSCC patients, resulting in low power. Besides, the guidelines used for defining cancer stages varied from the $6^{\text {th }}$ to the $8^{\text {th }}$ edition of the AJCC staging system, which might cause significant disparity among studies and affect the results. In addition, the publication bias could not be assessed because the number of studies included in each quantitative analysis was $<10(37,42)$. Finally, the adjusted HRs were analyzed, but the covariates used for adjustment varied considerably among the included studies, probably contributing to heterogeneity and suggesting that the results should be taken with caution.

In conclusion, the presence of PNI significantly affects the locoregional recurrence and survival outcomes among patients with OTSCC. Extensive prospective studies should thoroughly investigate the impact of PNI in OTSCC as it is strongly affecting OTSCC locoregional recurrence and patient survival. The heterogeneity of the prognostic outcomes according to PNI among different cancer stages should be analyzed and discussed in the future.

\section{DATA AVAILABILITY STATEMENT}

The original contributions presented in the study are included in the article/Supplementary Material. Further inquiries can be directed to the corresponding author.

\section{AUTHOR CONTRIBUTIONS}

JL conceived and coordinated the study, designed, performed, and analyzed the experiments, wrote the paper. JL and SL carried out the data collection, data analysis and revised the paper. All authors contributed to the article and approved the submitted version.

\section{FUNDING}

This study was supported by the Fundamental and Applied Fundamental Research Project of West China Hospital of Stomatology Sichuan University (Grant: RD-02-201909) and the National Natural Science Foundation of China (Grant: 81902775).

\section{ACKNOWLEDGMENTS}

We would like to thank all the contributors for their contributions to this study.

\section{SUPPLEMENTARY MATERIAL}

The Supplementary Material for this article can be found online at: https://www.frontiersin.org/articles/10.3389/fonc.2021. 683825/full\#supplementary-material 


\section{REFERENCES}

1. Bray F, Ferlay J, Soerjomataram I, Siegel RL, Torre LA, Jemal A. Global Cancer Statistics 2018: GLOBOCAN Estimates of Incidence and Mortality Worldwide for 36 Cancers in 185 Countries. CA Cancer J Clin (2018) 68 (6):394-424. doi: 10.3322/caac.21492

2. Siegel RL, Miller KD, Jemal A. Cancer Statistics, 2020. CA Cancer J Clin (2020) 70(1):7-30. doi: 10.3322/caac.21590

3. Shield KD, Ferlay J, Jemal A, Sankaranarayanan R, Chaturvedi AK, Bray F, et al. The Global Incidence of Lip, Oral Cavity, and Pharyngeal Cancers by Subsite in 2012. CA Cancer J Clin (2017) 67(1):51-64. doi: 10.3322/ caac. 21384

4. Jemal A, Bray F, Center MM, Ferlay J, Ward E, Forman D. Global Cancer Statistics. CA Cancer J Clin (2011) 61(2):69-90. doi: 10.3322/caac.20107

5. Pfister DG, Spencer S, Adelstein D, Adkins D, Brizel DM, Bruce JY, et al. NCCN Clinical Practice Guidelines in Oncology (NCCN Guidelines). Head and Neck Cancers. Version 3.2021. Fort Washington: National Comprehensive Cancer Network (2021).

6. Kim YJ, Kim JH. Increasing Incidence and Improving Survival of Oral Tongue Squamous Cell Carcinoma. Sci Rep (2020) 10(1):7877. doi: 10.1038/ s41598-020-64748-0

7. Rusthoven K, Ballonoff A, Raben D, Chen C. Poor Prognosis in Patients With Stage I and II Oral Tongue Squamous Cell Carcinoma. Cancer (2008) 112 (2):345-51. doi: 10.1002/cncr.23183

8. Chen SH, Zhang BY, Zhou B, Zhu CZ, Sun LQ, Feng YJ. Perineural Invasion of Cancer: A Complex Crosstalk Between Cells and Molecules in the Perineural Niche. Am J Cancer Res (2019) 9(1):1-21.

9. Knijn N, Mogk SC, Teerenstra S, Simmer F, Nagtegaal ID. Perineural Invasion Is a Strong Prognostic Factor in Colorectal Cancer: A Systematic Review. Am J Surg Pathol (2016) 40(1):103-12. doi: 10.1097/PAS.0000000000000518

10. Chen JW, Xie JD, Ling YH, Li P, Yan SM, Xi SY, et al. The Prognostic Effect of Perineural Invasion in Esophageal Squamous Cell Carcinoma. BMC Cancer (2014) 14:313. doi: 10.1186/1471-2407-14-313

11. Gadducci A, Pistolesi S, Cosio S, Naccarato AG. Is Perineural Invasion a Novel Prognostic Factor Useful to Tailor Adjuvant Treatment in Patients Treated With Primary Surgery for Cervical and Vulvar Carcinoma? Anticancer Res (2020) 40(6):3031-7. doi: 10.21873/anticanres.14283

12. Liebig C, Ayala G, Wilks JA, Berger DH, Albo D. Perineural Invasion in Cancer: A Review of the Literature. Cancer (2009) 115(15):3379-91. doi: $10.1002 /$ cncr.24396

13. Dunn M, Morgan MB, Beer TW. Perineural Invasion: Identification, Significance, and a Standardized Definition. Dermatol Surg (2009) 35 (2):214-21. doi: 10.1111/j.1524-4725.2008.34412.x

14. Bernier J, Domenge C, Ozsahin M, Matuszewska K, Lefebvre JL, Greiner RH, et al. Postoperative Irradiation With or Without Concomitant Chemotherapy for Locally Advanced Head and Neck Cancer. N Engl J Med (2004) 350 (19):1945-52. doi: 10.1056/NEJMoa032641

15. Bernier J, Cooper JS, Pajak TF, van Glabbeke M, Bourhis J, Forastiere A, et al. Defining Risk Levels in Locally Advanced Head and Neck Cancers: A Comparative Analysis of Concurrent Postoperative Radiation Plus Chemotherapy Trials of (\#22931) and RTOG (\# 9501). Head Neck (2005) 27(10):843-50. doi: 10.1002/hed.20279

16. Cooper JS, Zhang Q, Pajak TF, Forastiere AA, Jacobs J, Saxman SB, et al. Long-Term Follow-Up of the RTOG 9501/Intergroup Phase III Trial: Postoperative Concurrent Radiation Therapy and Chemotherapy in HighRisk Squamous Cell Carcinoma of the Head and Neck. Int J Radiat Oncol Biol Phys (2012) 84(5):1198-205. doi: 10.1016/j.jirobp.2012.05.008

17. Sher DJ, Adelstein DJ, Bajaj GK, Brizel DM, Cohen EEW, Halthore A, et al. Radiation Therapy for Oropharyngeal Squamous Cell Carcinoma: Executive Summary of an ASTRO Evidence-Based Clinical Practice Guideline. Pract Radiat Oncol (2017) 7(4):246-53. doi: 10.1016/j.prro.2017.02.002

18. Babington S, Veness MJ, Cakir B, Gebski VJ, Morgan GJ. Squamous Cell Carcinoma of the Lip: Is There a Role for Adjuvant Radiotherapy in Improving Local Control Following Incomplete or Inadequate Excision? ANZ J Surg (2003) 73(8):621-5. doi: 10.1046/j.1445-2197.2003.t01-1-02710.x

19. Rajappa SK, Ram D, Shukla H, Mandal G, Venkatasubramaniyan M, Dubey A, et al. Oncological Benefits of Postoperative Radiotherapy in Node-Negative Early Stage Cancer of the Oral Cavity With Isolated
Perineural Invasion. Br J Oral Maxillofac Surg (2019) 57(5):454-9. doi: 10.1016/j.bjoms.2019.04.002

20. Ling W, Mijiti A, Moming A. Survival Pattern and Prognostic Factors of Patients With Squamous Cell Carcinoma of the Tongue: A Retrospective Analysis of 210 Cases. J Oral Maxillofac Surg (2013) 71(4):775-85. doi: 10.1016/j.joms.2012.09.026

21. Cho Y, Yoon HI, Lee IJ, Kim JW, Lee CG, Choi EC, et al. Patterns of Local Recurrence After Curative Resection and Reconstruction for Oropharyngeal and Oral Cancers: Implications for Postoperative Radiotherapy Target Volumes. Head Neck (2019) 41(11):3916-23. doi: 10.1002/hed.25928

22. Newman M, Dziegielewski PT, Nguyen NTA, Seikaly HS, Xie M, O'Connell DA, et al. Relationship of Depth of Invasion to Survival Outcomes and Patterns of Recurrence for T3 Oral Tongue Squamous Cell Carcinoma. Oral Oncol (2021) 116:105195. doi: 10.1016/j.oraloncology.2021.105195

23. Chatzistefanou I, Lubek J, Markou K, Ord RA. The Role of Neck Dissection and Postoperative Adjuvant Radiotherapy in Cn0 Patients With PNI-Positive Squamous Cell Carcinoma of the Oral Cavity. Oral Oncol (2014) 50(8):753-8. doi: 10.1016/j.oraloncology.2014.05.005

24. Matsushita Y, Yanamoto S, Takahashi H, Yamada S, Naruse T, Sakamoto Y, et al. A Clinicopathological Study of Perineural Invasion and Vascular Invasion in Oral Tongue Squamous Cell Carcinoma. Int J Oral Maxillofac Surg (2015) 44(5):543-8. doi: 10.1016/j.ijom.2015.01.018

25. Almangush A, Bello IO, Coletta RD, Makitie AA, Makinen LK, Kauppila JH, et al. For Early-Stage Oral Tongue Cancer, Depth of Invasion and Worst Pattern of Invasion Are the Strongest Pathological Predictors for Locoregional Recurrence and Mortality. Virchows Arch (2015) 467(1):39-46. doi: 10.1007/ s00428-015-1758-z

26. Cracchiolo JR, Xu B, Migliacci JC, Katabi N, Pfister DG, Lee NY, et al. Patterns of Recurrence in Oral Tongue Cancer With Perineural Invasion. Head Neck (2018) 40(6):1287-95. doi: 10.1002/hed.25110

27. Durr ML, van Zante A, Li D, Kezirian EJ, Wang SJ. Oral Tongue Squamous Cell Carcinoma in Never-Smokers: Analysis of Clinicopathologic Characteristics and Survival. Otolaryngol Head Neck Surg (2013) 149(1):8996. doi: $10.1177 / 0194599813482876$

28. Marra A, Violati M, Broggio F, Codeca C, Blasi M, Luciani A, et al. Long-Term Disease-Free Survival in Surgically-Resected Oral Tongue Cancer: A 10-Year Retrospective Study. Acta Otorhinolaryngol Ital (2019) 39(2):84-91. doi: 10.14639/0392-100X-2336

29. Mascitti M, Zhurakivska K, Togni L, Caponio VCA, Almangush A, Balercia P, et al. Addition of the Tumour-Stroma Ratio to the 8th Edition American Joint Committee on Cancer Staging System Improves Survival Prediction for Patients With Oral Tongue Squamous Cell Carcinoma. Histopathology (2020) 77(5):810-22. doi: 10.1111/his.14202

30. Ong HS, Gokavarapu S, Tian Z, Li J, Cao W, Zhang CP. Does a Mandibular Access Osteotomy Improve Survival in pT2 Oral Tongue Cancers? Retrospective Study at a Single Institution. Int J Oral Maxillofac Surg (2018) 47(3):289-95. doi: 10.1016/j.ijom.2017.08.010

31. Peng KA, Chu AC, Lai C, Grogan T, Elashoff D, Abemayor E, et al. Is There a Role for Neck Dissection in T1 Oral Tongue Squamous Cell Carcinoma? The UCLA Experience. Am J Otolaryngol (2014) 35(6):741-6. doi: 10.1016/ j.amjoto.2014.06.019

32. Sharma K, Ahlawat P, Gairola M, Tandon S, Sachdeva N, Sharief MI. Prognostic Factors, Failure Patterns and Survival Analysis in Patients With Resectable Oral Squamous Cell Carcinoma of the Tongue. Radiat Oncol J (2019) 37(2):73-81. doi: 10.3857/roj.2018.00577

33. Shen WR, Wang YP, Chang JY, Yu SY, Chen HM, Chiang CP. Perineural Invasion and Expression of Nerve Growth Factor can Predict the Progression and Prognosis of Oral Tongue Squamous Cell Carcinoma. J Oral Pathol Med (2014) 43(4):258-64. doi: 10.1111/jop.12133

34. Caponio VCA, Troiano G, Togni L, Zhurakivska K, Santarelli A, Laino L, et al. Pattern and Localization of Perineural Invasion Predict Poor Survival in Oral Tongue Carcinoma. Oral Dis (2021). doi: 10.1111/odi.13900

35. Page MJ, McKenzie JE, Bossuyt PM, Boutron I, Hoffmann TC, Mulrow CD, et al. The PRISMA 2020 Statement: An Updated Guideline for Reporting Systematic Reviews. BMJ (2021) 372:n71.

36. Aslam S, Emmanuel P. Formulating a Researchable Question: A Critical Step for Facilitating Good Clinical Research. Indian J Sex Transm Dis AIDS (2010) 31(1):47-50. doi: 10.4103/0253-7184.69003 
37. Higgins JPT, Thomas J, Chandler J, Cumpston M, Li T, Page MJ, et al. Cochrane Handbook for Systematic Reviews of Interventions Version 6.0 (Updated July 2019). London: Cochrane Collaboration (2019).

38. Lo CK, Mertz D, Loeb M. Newcastle-Ottawa Scale: Comparing Reviewers' to Authors' Assessments. BMC Med Res Methodol (2014) 14:45. doi: 10.1186/ 1471-2288-14-45

39. Slim K, Nini E, Forestier D, Kwiatkowski F, Panis Y, Chipponi J. Methodological Index for Non-Randomized Studies (Minors): Development and Validation of a New Instrument. ANZ J Surg (2003) 73(9):712-6. doi: 10.1046/j.1445-2197.2003.02748.x

40. Guyatt GH, Oxman AD, Schunemann HJ, Tugwell P, Knottnerus A. GRADE Guidelines: A New Series of Articles in the Journal of Clinical Epidemiology. J Clin Epidemiol (2011) 64(4):380-2. doi: 10.1016/j.jclinepi.2010.09.011

41. Tufanaru C, Munn Z, Stephenson M, Aromataris E. Fixed or Random Effects Meta-Analysis? Common Methodological Issues in Systematic Reviews of Effectiveness. Int J Evid Based Healthc (2015) 13(3):196-207. doi: 10.1097/ XEB. 0000000000000065

42. Higgins JP, Altman DG, Gotzsche PC, Juni P, Moher D, Oxman AD, et al. The Cochrane Collaboration's Tool for Assessing Risk of Bias in Randomised Trials. BMJ (2011) 343:d5928. doi: 10.1136/bmj.d5928

43. Yang X, Tian X, Wu K, Liu W, Li S, Zhang Z, et al. Prognostic Impact of Perineural Invasion in Early Stage Oral Tongue Squamous Cell Carcinoma: Results From a Prospective Randomized Trial. Surg Oncol (2018) 27(2):123-8. doi: 10.1016/j.suronc.2018.02.005

44. Choi N, Cho JK, Lee EK, Won SJ, Kim BY, Baek CH. Transoral Bisected Resection for T1-2 Oral Tongue Squamous Cell Carcinoma to Secure Adequate Deep Margin. Oral Oncol (2017) 73:70-6. doi: 10.1016/ j.oraloncology.2017.08.005

45. Subramaniam N, Balasubramanian D, Low TH, Vidhyadharan S, Menon A, Murthy S, et al. Squamous Cell Carcinoma of the Oral Tongue in Young Patients: Outcomes and Implications for Treatment. Indian J Surg Oncol (2020) 11(2):274-80. doi: 10.1007/s13193-020-01049-y

46. Xu C, Li H, Seng D, Liu F. Significance of SUV Max for Predicting Occult Lymph Node Metastasis and Prognosis in Early-Stage Tongue Squamous Cell Carcinoma. J Oncol (2020) 2020:6241637. doi: 10.1155/2020/6241637

47. De Paz D, Chang KP, Kao HK, Lao WW, Huang YC, Chang YL, et al. Clinical Implications of Tumor-Associated Tissue Eosinophilia in Tongue Squamous Cell Carcinoma. Laryngoscope (2019) 129(5):1123-9. doi: 10.1002/lary.27413

48. Goodman M, Liu L, Ward K, Zhang J, Almon L, Su G, et al. Invasion Characteristics of Oral Tongue Cancer: Frequency of Reporting and Effect on Survival in a Population-Based Study. Cancer (2009) 115(17):4010-20. doi: $10.1002 / \mathrm{cncr} .24459$

49. Sridharan S, Thompson LDR, Purgina B, Sturgis CD, Shah AA, Burkey B, et al. Early Squamous Cell Carcinoma of the Oral Tongue With Histologically Benign Lymph Nodes: A Model Predicting Local Control and Vetting of the Eighth Edition of the American Joint Committee on Cancer Pathologic T Stage. Cancer (2019) 125(18):3198-207. doi: 10.1002/cncr.32199

50. Thiagarajan S, Nair S, Nair D, Chaturvedi P, Kane SV, Agarwal JP, et al. Predictors of Prognosis for Squamous Cell Carcinoma of Oral Tongue. J Surg Oncol (2014) 109(7):639-44. doi: 10.1002/jso.23583

51. Bakst RL, Wong RJ. Mechanisms of Perineural Invasion. J Neurol Surg B Skull Base (2016) 77(2):96-106. doi: 10.1055/s-0036-1571835

52. Saidak Z, Lailler C, Clatot F, Galmiche A. Perineural Invasion in Head and Neck Squamous Cell Carcinoma: Background, Mechanisms, and Prognostic Implications. Curr Opin Otolaryngol Head Neck Surg (2020) 28(2):90-5. doi: 10.1097/MOO.0000000000000610

53. Marchesi F, Piemonti L, Mantovani A, Allavena P. Molecular Mechanisms of Perineural Invasion, a Forgotten Pathway of Dissemination and Metastasis. Cytokine Growth Factor Rev (2010) 21(1):77-82. doi: 10.1016/j.cytogfr. 2009.11.001

54. Zhang M, Zhu ZL, Gao XL, Wu JS, Liang XH, Tang YL. Functions of Chemokines in the Perineural Invasion of Tumors (Review). Int J Oncol (2018) 52(5):1369-79. doi: 10.3892/ijo.2018.4311
55. Zhu J, Zhou R, Wang Y, Yu M. Perineural Invasion as a Prognostic Factor in Head and Neck Squamous Cell Carcinoma: A Systematic Review and MetaAnalysis. Acta Otolaryngol (2019) 139(11):1038-43. doi: 10.1080/ 00016489.2019 .1655167

56. Ju J, Li Y, Chai J, Ma C, Ni Q, Shen Z, et al. The Role of Perineural Invasion on Head and Neck Adenoid Cystic Carcinoma Prognosis: A Systematic Review and Meta-Analysis. Oral Surg Oral Med Oral Pathol Oral Radiol (2016) 122 (6):691-701. doi: 10.1016/j.oooo.2016.08.008

57. Barrett AW, Speight PM. Perineural Invasion in Adenoid Cystic Carcinoma of the Salivary Glands: A Valid Prognostic Indicator? Oral Oncol (2009) 45 (11):936-40. doi: 10.1016/j.oraloncology.2009.07.001

58. Dantas AN, Morais EF, Macedo RA, Tinoco JM, Morais Mde L. Clinicopathological Characteristics and Perineural Invasion in Adenoid Cystic Carcinoma: A Systematic Review. Braz J Otorhinolaryngol (2015) 81 (3):329-35. doi: 10.1016/j.bjorl.2014.07.016

59. Cui L, Shi Y, Zhang GN. Perineural Invasion as a Prognostic Factor for Cervical Cancer: A Systematic Review and Meta-Analysis. Arch Gynecol Obstet (2015) 292(1):13-9. doi: 10.1007/s00404-015-3627-z

60. Gao A, Wang L, Li J, Li H, Han Y, Ma X, et al. Prognostic Value of Perineural Invasion in Esophageal and Esophagogastric Junction Carcinoma: A MetaAnalysis. Dis Markers (2016) 2016:7340180. doi: 10.1155/2016/7340180

61. Deng J, You Q, Gao Y, Yu Q, Zhao P, Zheng Y, et al. Prognostic Value of Perineural Invasion in Gastric Cancer: A Systematic Review and MetaAnalysis. PloS One (2014) 9(2):e88907. doi: 10.1371/journal.pone.0088907

62. Zhao B, Lv W, Mei D, Luo R, Bao S, Huang B, et al. Perineural Invasion as a Predictive Factor for Survival Outcome in Gastric Cancer Patients: A Systematic Review and Meta-Analysis. J Clin Pathol (2020) 73(9):544-51. doi: 10.1136/jclinpath-2019-206372

63. Rajasekaran Murugesan J, Prabhu Murugesan S, Yip J, Hitos K, Fulham S, Engel A. Meta-Analysis - Perineural Invasion as Prognostic Factor in Rectal Cancer. J Coloproctol (2019) 39(1):74-80. doi: 10.1016/j.jcol.2018.09.001

64. Bakst RL, Glastonbury CM, Parvathaneni U, Katabi N, Hu KS, Yom SS. Perineural Invasion and Perineural Tumor Spread in Head and Neck Cancer. Int J Radiat Oncol Biol Phys (2019) 103(5):1109-24. doi: 10.1016/ j.ijrobp.2018.12.009

65. Schmitd LB, Scanlon CS, D'Silva NJ. Perineural Invasion in Head and Neck Cancer. J Dent Res (2018) 97(7):742-50. doi: 10.1177/0022034518756297

66. Miller ME, Palla B, Chen Q, Elashoff DA, Abemayor E, St John MA, et al. A Novel Classification System for Perineural Invasion in Noncutaneous Head and Neck Squamous Cell Carcinoma: Histologic Subcategories and Patient Outcomes. Am J Otolaryngol (2012) 33(2):212-5. doi: 10.1016/ j.amjoto.2011.06.003

67. Williams LS, Mancuso AA, Mendenhall WM. Perineural Spread of Cutaneous Squamous and Basal Cell Carcinoma: CT and MR Detection and Its Impact on Patient Management and Prognosis. Int J Radiat Oncol Biol Phys (2001) 49 (4):1061-9. doi: 10.1016/s0360-3016(00)01407-3

68. da Silva SD, Kowalski LP. Perineural Invasion in Oral Cancer: Challenges, Controversies and Clinical Impact. Chin Clin Oncol (2019) 8(S1):S5. doi: $10.21037 /$ cco.2018.11.04

69. Hu G, Li L, Hu K. Clinical Implications of Perineural Invasion in Patients With Colorectal Cancer. Med (Baltimore) (2020) 99(17):e19860. doi: 10.1097/ MD.0000000000019860

Conflict of Interest: The authors declare that the research was conducted in the absence of any commercial or financial relationships that could be construed as a potential conflict of interest.

Copyright $\odot 2021 \mathrm{Li}, \mathrm{Liu}, \mathrm{Li}$, Han and Que. This is an open-access article distributed under the terms of the Creative Commons Attribution License (CC BY). The use, distribution or reproduction in other forums is permitted, provided the original author(s) and the copyright owner(s) are credited and that the original publication in this journal is cited, in accordance with accepted academic practice. No use, distribution or reproduction is permitted which does not comply with these terms. 